\title{
当科に括ける中耳手術の臨床的検討
}

渡部 浩・平川 勝洋・鈴木 衞 - 浜井 行夫
森 良樹・大野木 信・堀部よし恵・安藤
理加
井門謙太郎・高本 宗男・河野 裕之・夜陣
紘治
原田 康夫

\section{Clinical Evaluation of Middle Ear Surgery}

Hiroshi Watanabe, Katsuhiro Hirakawa, Mamoru Suzuki, Yukio Hamai, Yoshiki Mori, Makoto Onogi, Yoshie Horibe, Rika Andoh, Kentaro Imon, Muneo Takamoto, Hiroyuki Kouno, Koji Yajin and Yasuo Harada

(Hiroshima University)

The outcomes of 205 middle ear surgeries performed between 1987 and 1991 were reviewed.

Cholesteatoma was found in $51.7 \%$ and chronic otitis media in $22.9 \%$. Type I tympanoplasty was performed in $20.9 \%$, modified type III in $31.2 \%$, and modified type $\mathrm{N}$ in $7.3 \%$.

The rate of hearing improvement was $85 \%$ in those receiving type I surgery, $73.3 \%$ in those receiving modified type III surgery, and $69.2 \%$ in those receiving modified type $\mathbb{N}$ surgery. Autocartilage, autobone, and prosthesis were used for ossiclar reconstruction. Autocartilage yielded the best improvements in hearing.

Key words: tympanoplasty, statistical analysis, hearing result, ossiclar reconstruction

緒言

近年, 中耳手術は一般的な手術として多くの 施設で行なわれ，良好な成績が収められている. 当科に执ける真珠腫性中耳炎の再発㧍よびアブ ミ骨手術の聴力成績についてはすでに報告し た12). 今回は最近 5 年間に行なった中耳手術 について術後聴力成績を中心に検討したので報 告する.

対象および方法

対象は，1987年 1 月より1991年12月までの 5
年間に当科で中耳手術を行なった164例，205耳 とした.

鼓室形成術としては，I 型，II型変法， N 型 変法, 扣よび $\mathrm{O}$ 型が行なわれた（O型とは鼓 膜穿孔を閉鎖し，耳小骨連鎖の再建を行なわず に鼓室腔の安定化を計る術式で, 段階手術の 1 回目などに行なう3)。

聴力成績の検討は術後 6 力月以上聴力の推移 が追跡しえた症例を対象とした．聴力の評価は 4 分法で行ない，気骨導差は術前，術後それぞ 
れの骨導聴力レベルを用い，中野ら4)による聴 力成績の判定基準を用いた。つまり 1 ) 気骨導 差が $20 \mathrm{~dB}$ 以内， 2 ) 術後聴力レベルが $40 \mathrm{~dB}$ 以内, 3 ) 聴力改善が $15 \mathrm{~dB}$ 以上のいずれかを 満たすものを成功例とした. 気骨導差による判 定は， $-10 \sim 10 \mathrm{~dB}$ を著明改善，11〜 $20 \mathrm{~dB}$ を 改善, $21 \sim 30 \mathrm{~dB}$ をやや改善, $31 \mathrm{~dB} \sim$ を不良 とした.

\section{結果}

\section{1. 年齢と性別}

手術時年齢は 4 歳から69歳までで平均 32.5 歳 であった．性別は男性が87例(53\%)，女性は77 例 $(47 \%)$ であった．図 1 は年齢別疾患耳数であ
るが，年齢分布は二峰性で10歳代および40歳代 にピークがあった。

\section{2 . 疾患打よび術式}

疾患別耳数は真珠腫性中耳炎が 106 耳と最多 で半数以上をしめ, 逆に慢性中耳炎が 47 耳と少 なかった。 以下，中耳奇形が 15 耳，中耳炎術後 症が 12 耳, 癒着性中耳炎が 10 耳, 外傷性鼓膜穿 孔が 6 耳, 耳硬化症が 6 耳, 外傷性耳小骨離断 が 2 耳, コレステリン肉芽腫が 1 耳であった(図 2 ).

術式別耳数は鼓室形成術 $\mathrm{O}$ 型が57耳, I 型が 43 耳， III型変法が 64 耳， N 型変法が 15 耳，アブ ミ骨手術が15耳，その他単純乳突洞削開術等が

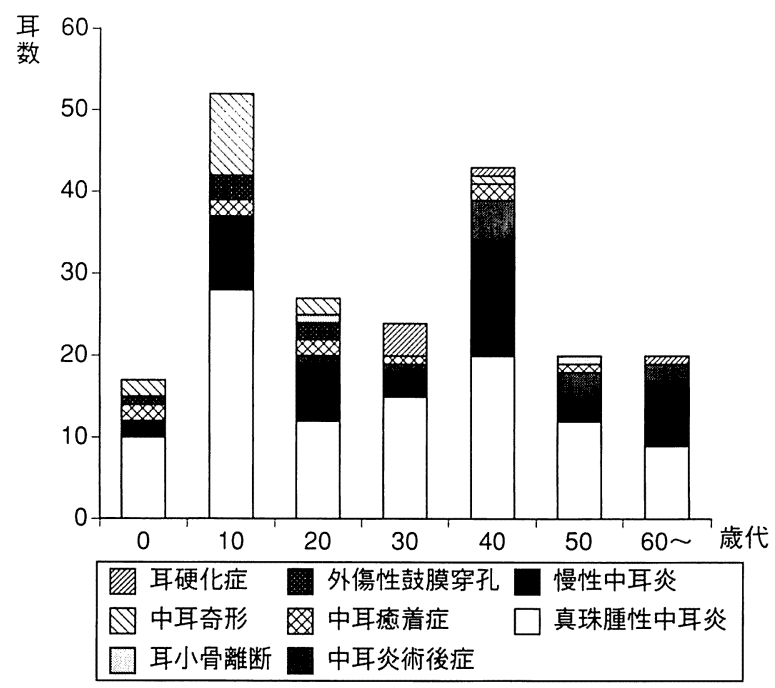

図 1 疾患別年秢分布

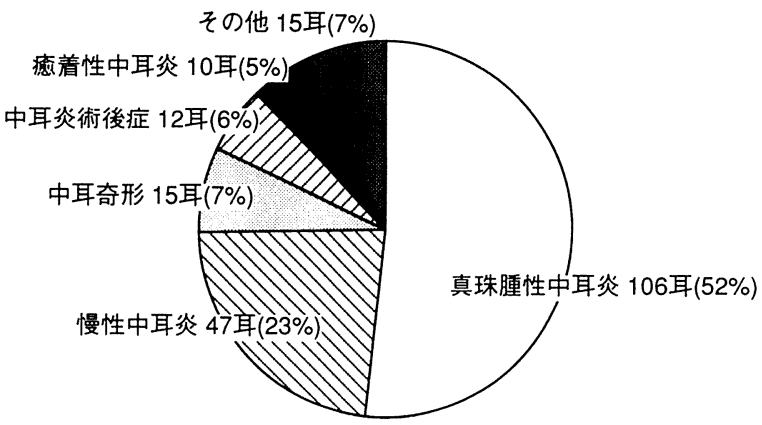

図 2 病型 
11耳であった(図 3 ).

待機中のものを除き，段階手術を行なったも のが全部で29例あった，その内訳は，真珠腫性 中耳炎が全71例中 26 例で $36.6 \%$, 瘉着性中耳炎 が全 8 例中 2 例で $25 \%$, 慢性中耳炎が全44例中 1 例で2. $2 \%$ であった。 その最終術式の内訳は 表 1 に示した.

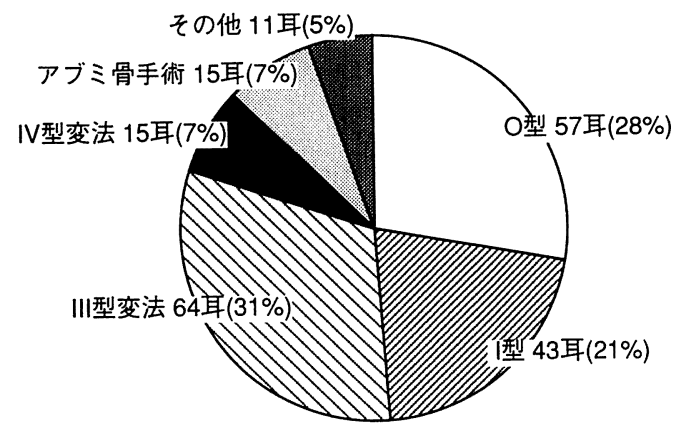

図 3 術式
3 . 術式・疾患別聴力成績

1) I 型聴力成績

評価のできた 32 耳について検討した．表 2 は 疾患別の聴力改善成功率である. 慢性中耳炎が 20 耳中 17 耳 $285 \%$ の成功率であった。他の疾患 の成功率は, 真珠腫性中耳炎が 3 耳中 3 耳, 瘉 着性中耳炎が 1 耳中 1 耳, 外傷性鼓膜穿孔が 5 耳中 5 耳で $100 \%$ ，中耳炎術後症が 2 耳中 1 耳 で $50 \%$ ，コレステリン肉芽腫が 1 耳中 0 耳で 0 \%であり，全体として $84.4 \%$ の成功率であった。

2 ）吕型変法聴力成績

評価のできた 45 耳について検討した，表 3 は 疾患別の聴力改善成功率である. 真珠腫性中耳 炎が 27 耳中 17 耳と $62.9 \%$ の成功率であった．他 の疾患の成功率は，慢性中耳炎が 6 耳中 6 耳, 中耳奇形が 4 耳中 4 耳, 耳小骨離断が 2 耳中 2 耳，癒着性中耳炎が 2 耳中 2 耳で $100 \%$ ，中耳 炎術後症が 4 耳中 2 耳で $50 \%$ であり，全体とし て73.3\%の成功率であった。

表 1 段階手術の術式

\begin{tabular}{c|c|c|c|c}
\hline \hline & 真珠腫性中耳炎 & 癒着性中耳炎 & 慢性中耳炎 & 合計 \\
\hline $\mathrm{O}$ 型 $\rightarrow$ III 型 & $22 / 71(30.9 \%)$ & $1 / 8(12.5 \%)$ & $1 / 44(2.2 \%)$ & 24 \\
\hline $\mathrm{O}$ 型 $\rightarrow \mathrm{N}$ 型 & $4 / 71(5.6 \%)$ & $1 / 8(12.5 \%)$ & $0 / 44(0 \%)$ & 5 \\
\hline 合計 & $26 / 71(36.6 \%)$ & $2 / 8(25 \%)$ & $1 / 44(2.2 \%)$ & 29
\end{tabular}

表 2 I 型疾患別聴力成績

\begin{tabular}{|c|c|c|c|c|c|}
\hline \multirow[b]{2}{*}{ 疾 患 } & \multirow[b]{2}{*}{ 耳数 } & \multicolumn{3}{|c|}{ 術後聴力 (\%) } & \multirow[b]{2}{*}{$\begin{array}{c}\text { 成功耳数 } \\
(\%)\end{array}$} \\
\hline & & $\begin{array}{c}\text { 聴力レベル } \\
40 \mathrm{~dB} \\
\text { 以内 }\end{array}$ & $\begin{array}{c}\text { 聴力改善 } \\
15 \mathrm{~dB} \\
\text { 以上 }\end{array}$ & $\begin{array}{c}\text { 気骨導差 } \\
20 \mathrm{~dB} \\
\text { 以内 }\end{array}$ & \\
\hline 慢性中耳炎 & 20 & $16(80)$ & $7(35)$ & $15 \quad(75)$ & $17 \quad(85)$ \\
\hline 真珠腫性中耳炎 & 3 & $3(100)$ & $0(0)$ & $2(66.7)$ & $3(100)$ \\
\hline 中耳炎術後症 & 2 & $0 \quad(0)$ & $0(0)$ & $1 \quad(50)$ & $1 \quad(50)$ \\
\hline 癒着性中耳炎 & 1 & $1(100)$ & $0(0)$ & $1(100)$ & $1(100)$ \\
\hline コレステリン肉芽腫 & 1 & $0 \quad(0)$ & $0(0)$ & $0 \quad(0)$ & $0 \quad(0)$ \\
\hline 外傷珄鼓膜穿孔 & 5 & $5(100)$ & $1(20)$ & $5(100)$ & $5(100)$ \\
\hline 合 & 32 & $25(78.1)$ & $8(25)$ & $24(75)$ & $27(84.4)$ \\
\hline
\end{tabular}




\section{3） N 型変法聴力成績}

評価のできた13耳について検討した．表 4 は 疾患別の聴力改善成功率である. 真珠腫性中耳 炎が 9 耳中 6 耳と $66.7 \%$ の成功率であった。 他 の疾患の成功率は, 中耳炎術後症が 1 耳中 1 耳, 中耳奇形が 1 耳中 1 耳で $100 \%$, 癒着性中耳炎 が 2 耳中 1 耳で $50 \%$ であり，全体として $69.2 \%$ の成功率であった.

\section{4.小児および高歯者の聴力成績}

15歳以下の小児症例で聴力評価ができたもの は25耳であった。慢性中耳炎は 9 耳あり, 術式 は I 型が 7 耳, III型変法が 2 耳であった. 真珠 腫性中耳炎は 7 耳あり， III型変法が 6 耳, $\mathbb{N}$ 型 変法が 1 耳であった。 中耳奇形は 4 耳あり， III 型変法が 3 耳, $\mathbb{N}$ 型変法が 1 耳であった。他は 全例 I 型であった. 表 5 は疾患別の聴力改善成
功耳数および気骨導差による判定結果である. 成功率は慢性中耳炎が $100 \%$, 真珠腫性中耳炎 が71.4\%で全体としては88\%であった.

60歳以上の高齢者で聴力評価ができたものは 7 耳であった。慢性中耳炎が 3 耳めり，術式は I 型が 2 耳, III型变法が 1 耳であった. 真珠腫 性中耳炎は 3 耳あり, I 型, II 型変法, $\mathrm{N}$ 型変 法それぞれ 1 耳ずつであった。中耳炎術後症 1 耳には I 型を行なっていた．表 6 は疾患別の聴 力改善成功耳数拉よび気骨導差による判定結果 である，成功率は慢性中耳炎が $66.7 \%$ ，真珠腫 性中耳炎が100\%で全体としては $85.7 \%$ であっ た.

5. コルメラ別聴力成績

III型および $\mathbb{N}$ 型変法に用いたコルメラ材料別 の聴力成績を表 7 に示した．軟骨は自家の耳珠

表 3 III型变法疾患別聴力成績

\begin{tabular}{|c|c|c|c|c|c|}
\hline \multirow[b]{2}{*}{ 疾 患 } & \multirow[b]{2}{*}{ 耳数 } & \multicolumn{3}{|c|}{ 術後聴力 (\%) } & \multirow[b]{2}{*}{$\begin{array}{c}\text { 成功耳数 } \\
(\%)\end{array}$} \\
\hline & & $\begin{array}{c}\text { 聴力レベル } \\
40 \mathrm{~dB} \\
\text { 以内 }\end{array}$ & $\begin{array}{c}\text { 聴力改善 } \\
15 \mathrm{~dB} \\
\text { 以上 }\end{array}$ & $\begin{array}{c}\text { 気骨導差 } \\
20 \mathrm{~dB} \\
\text { 以内 }\end{array}$ & \\
\hline & 27 & $15(55.6)$ & $7(25.9)$ & $13(48.1)$ & $17(62.9)$ \\
\hline $\begin{array}{l}\text { 真珠腫性中耳炎 } \\
\text { 慢性中耳炎 }\end{array}$ & 6 & $4(66.7)$ & $3 \quad(50)$ & $5(83.3)$ & $6(100)$ \\
\hline 中耳炎術後症 & 4 & $2 \quad(50)$ & $2 \quad(50)$ & $2 \quad(50)$ & $2 \quad(50)$ \\
\hline 中耳奇形 & 4 & $4(100)$ & $3 \quad(75)$ & $3 \quad(75)$ & $4(100)$ \\
\hline 耳小骨離断 & 2 & $1 \quad(50)$ & $2(100)$ & $2(100)$ & $2(100)$ \\
\hline 癒着性中耳炎 & 2 & $2(100)$ & $0 \quad(0)$ & $2(100)$ & $2(100)$ \\
\hline 合 計 & 45 & $28(62.2)$ & $17(37.8)$ & $27(60)$ & $33(73.3)$ \\
\hline
\end{tabular}

表 $4 \quad \mathrm{~N}$ 型变法疾患別聴力成績

\begin{tabular}{|c|c|c|c|c|c|}
\hline \multirow[b]{2}{*}{ 疾 } & \multirow[b]{2}{*}{ 耳数 } & \multicolumn{3}{|c|}{ 術後聴力 (\%) } & \multirow[b]{2}{*}{$\begin{array}{c}\text { 成功耳数 } \\
(\%)\end{array}$} \\
\hline & & $\begin{array}{c}\text { 聴力レベル } \\
40 \mathrm{~dB} \\
\text { 以内 }\end{array}$ & $\begin{array}{c}\text { 聴力改善 } \\
15 \mathrm{~dB} \\
\text { 以上 }\end{array}$ & $\begin{array}{c}\text { 気骨導差 } \\
20 \mathrm{~dB} \\
\text { 以内 }\end{array}$ & \\
\hline 真珠腫珄中耳炎 & 9 & $4(44.4)$ & $1(11.1)$ & $5(55.6)$ & $6(66.7)$ \\
\hline 癒着珄中耳炎 & 2 & $0 \quad(0)$ & $1 \quad(50)$ & $0 \quad(0)$ & $1 \quad(50)$ \\
\hline 中耳炎術後症 & 1 & $1(100)$ & $1(100)$ & $1(100)$ & $1(100)$ \\
\hline 中耳奇形 & 1 & $1(100)$ & $1(100)$ & $1(100)$ & $1(100)$ \\
\hline 計 & 13 & $6(46.2)$ & $4(30.8)$ & $7(53.8)$ & $9(69.2)$ \\
\hline
\end{tabular}


あるいは舟状窩軟骨を用いたもの，骨は自家の 耳小骨あるいは皮質骨を用いたもの，人工耳小 骨は PORP あるいは TORPを用いたもの，骨 十軟骨は骨の上に軟骨を重ねてコルメラにした ものである．回型変法に摂いてコルメラに自家
軟骨を用いたものが 20 耳あり，著明改善が 7 耳， 改善以上の成功例が14耳であった，自家骨を用 いたものも20耳あり, 著明改善が 2 耳, 成功例 が12耳，不良例が 7 耳あった。人工耳小骨を用 いたものは 2 耳のみであった， $\mathrm{N}$ 型変法では軟

表 5 小児疾患別聴力成績

\begin{tabular}{|c|c|c|c|c|c|c|}
\hline \multirow{2}{*}{ 疾 患 } & \multirow{2}{*}{ 総耳数 } & \multirow{2}{*}{ 成功耳数 (\%) } & \multicolumn{4}{|c|}{ 気骨導差による判定 } \\
\hline & & & 著明改善 & 改善 & やや改善 & 不良 \\
\hline 慢性中耳炎 & 9 & $9(100)$ & 3 & 4 & 2 & 0 \\
\hline 真珠腫性中耳炎 & 7 & $5(71.4)$ & 3 & 1 & 1 & 2 \\
\hline 中耳奇形 & 4 & $4(100)$ & 1 & 2 & 1 & 0 \\
\hline 外傷性鼓膜穿孔 & 4 & $4(100)$ & 4 & 0 & 0 & 0 \\
\hline コレステリソ肉芽腫 & 1 & $0 \quad(0)$ & 0 & 0 & 0 & 1 \\
\hline 合 & 25 & $22 \quad(88)$ & 11 & 7 & 4 & 3 \\
\hline
\end{tabular}

表 6 高龄者疾患別聴力成績

\begin{tabular}{c|c|c|c|c|c|c}
\hline \hline \multirow{2}{*}{ 疾 患 } & \multirow{2}{*}{ 総耳数 } & \multirow{2}{*}{ 成功耳数(\%) } & \multicolumn{4}{|c}{ 気骨導差による判定 } \\
\cline { 4 - 7 } & & & 著明改善 & 改善 & やや改善 & 不良 \\
\hline 慢性中耳炎 & 3 & $2(66.7)$ & 1 & 0 & 1 & 1 \\
真珠腫性中耳炎 & 3 & $3(100)$ & 0 & 3 & 0 & 0 \\
中耳炎術後症 & 1 & $1(100)$ & 0 & 1 & 0 & 0 \\
\hline \multicolumn{1}{c|}{ 合 計 } & 7 & $6(85.7)$ & 1 & 4 & 1 & 1
\end{tabular}

表 7 コルメラ別聴力成績

\begin{tabular}{|c|c|c|c|c|c|c|c|}
\hline & & \multirow{2}{*}{ 総耳数 } & \multirow{2}{*}{ 成功耳数 (\%) } & \multicolumn{4}{|c|}{ 気骨導差による判定 } \\
\hline & & & & 著明改善 & 改善 & やや改善 & 不良 \\
\hline \multirow{5}{*}{ III型 } & 軟骨 & 20 & $16 \quad(80)$ & 7 & 7 & 3 & 3 \\
\hline & 骨 & 20 & $14 \quad(70)$ & 2 & 10 & 1 & 7 \\
\hline & 骨＋軟骨 & 3 & 1(33.3) & 0 & 1 & 1 & 1 \\
\hline & 人工耳小骨 & 2 & $2(100)$ & 0 & 1 & 1 & 0 \\
\hline & 計 & 45 & $33(73.3)$ & 9 & 19 & 6 & 11 \\
\hline \multirow{4}{*}{$\mathrm{N}$ 型 } & 軟骨 & 10 & $6 \quad(60)$ & 0 & 6 & 1 & 3 \\
\hline & 骨 & 2 & $2(100)$ & 0 & 0 & 1 & 1 \\
\hline & 人工耳小骨 & 1 & 1(100) & 0 & 0 & 1 & 0 \\
\hline & 計 & 13 & $9(69.2)$ & 0 & 6 & 3 & 4 \\
\hline \multicolumn{2}{|r|}{ 計 } & 58 & $42(72.4)$ & 9 & 25 & 9 & 15 \\
\hline
\end{tabular}


骨を用いたものが $10 耳 て ゙$ 著明改善例はなく改善 例は 6 耳であった。

\section{考察}

手術時年㱓分布は諸家の報告では30〜 40歳代 にピークをもつものが多(5)6). 当科に拀いて も40歳代にピークを認めたが，10歳代が最多で 年齢分布は二峰性となった。これは当科では10 歳代の真珠腫性中耳炎症例が28耳と多く, その 上中耳奇形を通常この年代に手術するためと思 われる。

近年, 鼓室形成術の対象は若年, 老年の双方 に拡がっている. 従来, 幼小児の鼓室形成術の 時期は上気道感染や耳管機能不全が落ちついて から行なら方が良いといわれていたが，最近で は成人と比較して手術成績に差がないので積極 的に手術をすべきであるといら報告が多(778). 当科の聴力成績でも慢性中耳炎, 外傷性鼓膜穿 孔は $100 \%$ の成功率であった。 また真珠腫性中 耳炎はいずれもコルメラ变法を行なっていたが, $71.4 \%$ の成功率で成人の成績を上回るものであ った。耳漏の排出和よび反対耳の状態に注意し つつ7) 今後も積極的に小览の鼓室形成術を行な いたいと思っている. 一方, 高齢者は全身的合 併症を伴らことが多い, 移植片が生着しにくい, 手術の成果がわずかな余命に対して見合わない 等の理由で㕝室形成術は禁忌とされていた ${ }^{9)}$. しかし, 平均寿命の延長, 手術手技の向上等に より最近では全身合併症に留意しつつ手術を行 なら傾向にある10). 当科では過去 5 年間に 60 歳 以上の高齢者に行なった中耳手術は20耳で全体 の9.8\%であった. 症例数は少ないが聴力成績 も成功率 $85.7 \%$ と良好であった。

鼓室形成術全体の聴力成績は I 型全体で 84.4 $\%$ ， III型変法が $73.3 \% ， \mathbb{N}$ 型変法が $69.2 \%$ と概 ね良好であった。しかしながら疾患別にみると， 慢性中耳炎に対しI型を行なった症例の成功率 は20耳中 17 耳 $(85 \%)$ と不満足なものである.こ の 3 耳の不成功例はいずれも上鼓室に肉芽が充 満していた症例で, 耳小骨周囲の肉芽を可及的 に除去したものであった。鼓室形成術に执いて
I 型手術が生理的で聴力改善が良好であり, 術

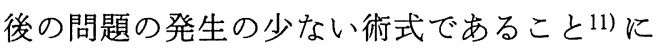
異論はない。しかしながら，耳小骨周囲の肉芽 形成が著明で術後に再び肉芽が増生したり，耳 小骨の可動性が制限されそうな症例にはコルメ ラ III型変法等の術式を考慮に入れることも術後 聴力成績の改善に必要と思われる.

聴力成績が評価できたコルメラ症例 58 耳の内, 当科に执いて使用したコルメラは自家軟骨が30 耳 $(51.7 \%)$ と最も多く, ついで自家骨の 22 耳 (37.9\%)であった．人工耳小骨の使用はわずか 3 耳であった。人工耳小骨は長期的な聴力の改 善が得られ，適当なコルメラ材料が採取できな いときに有用であるが，鼓室内に炎症がみられ たり耳管機能不全がある場合は露出, 排出等を きたし易い12)。当科で人工耳小骨を使用した症 例の聴力成績はいずれも成功しているが気骨導 差の判定では改善以上は 1 耳となる. 一方, 自 家軟骨を使用した例は，血型変法20耳中著明改 善が 7 耳, 改善が 7 耳, $\mathbb{N}$ 型変法でも 10 耳中 6 耳が改善と良好な成績であった。 また，自家骨 を使用した症例の聴力成績は自家軟骨を使用し たものより若干劣っていた．特に皮質骨を使用 したものは周囲と癒着し聴力低下をさたす症例 が少なからずみられ，こらいった症例の修正手 術は鈴木も指摘しているよう10)にかなり難渋 する. 今後, 長期的な聴力成績の検討が必要で あるが現在のところコルメラとしては自家軟骨 が最適と考えている.

\section{まとめ}

1 ） 1987年 1 月より 1991年12月までの 5 年間 に当科で行なった中耳手術症例について年齢, 性差, 病型, 術式, 聴力成績について統計的検 討を行なった。

2 ）鼓室形成術の聴力成績の成功率は I 型 $84.4 \%$, III型变法 $73.3 \%, \mathrm{~N}$ 型変法69.2\%であ った．15歳以下の小児例の成功率は $88 \% ， 60$ 歳 以上の高齢者の成功率は $85.7 \%$ であった。

3 ）自家軟骨をコルメラに使用したものが最 も気骨導差の改善が良好であった。 
文 献

1）鈴木 衞, 平田 思, 松島隆浩, 他 : 真珠腫性 中耳炎の臨床統計的観察. 耳鼻臨床 $84: 895 \sim$ 900, 1991.

2）永澤 昌, 平川勝洋, 有重秀三, 他 : アブミ骨 手術症例の検討. 広島医学 $43: 1593 \sim 1598$, 1990.

3）鈴木淳一：O型手術. 伝音性難聴へのアプロー チ. (鈴木淳一編). 183 187頁, 篠原出版, 東 京, 1983.

4）中野雄一, 本多芳男, 坂井 真, 他 : 鼓室形成 術の成績判定について(提案). 臨床耳科 14 : 306 307, 1987.

5）稲木勝秀, 長沼英明, 金子 功, 他: 教室15年 の耳手術の統計的観察. 臨床耳科 $14: 300 \sim 301$, 1987.

6）松岡秀樹, 村上匡孝, 後藤達也, 他 : 過去 12 年 間の耳科手術の統計的観察. 耳鼻臨床 $84: 17$ $\sim 25,1991$.

7）山本悦生, 大村正樹, 水上千佳司, 他: 小児の 鼓膜形成術の実施時期. 耳鼻臨床 $85: 203 \sim 207$,
1992.

8）宮永敏, 笠野藤彦, 東野哲也, 他: 小児に対 する鼓室形成術の適応.耳鼻 $38: 220 \sim 224$, 1992.

9) Schuknecht HF, McGee TM and Oleksiuk S : Comments on Tympanoplasty. Laryngoscope $70: 1157 \sim 1168,1960$.

10）寺薗富朗, 西村武重, 矢野原邦生, 他 : 高齢者 に拈ける中耳手術症例の検討. 日耳鼻 $89: 267$ $\sim 272,1986$.

11）鈴木淳一：I 型手術, コルメラ III型手術. 伝音 性難聴へのアプローチ（鈴木淳一編).171〜 178頁, 篠原出版, 東京, 1983.

12）佐伯忠彦, 暁清文, 柳原尚明, 他: 人工耳小 骨による伝音系再建術の成績. 耳鼻臨床 83 ： 1181 1188, 1990.

$$
\left(\begin{array}{l}
\text { 別刷請求先 : 渡部 浩 } \\
\mathbf{T} 734 \text { 広島市南区霞1-2-3 } \\
\text { 広島大学医学部耳鼻咽喉科学教室 }
\end{array}\right)
$$

